\title{
Growth and physiology of Carcinus maenas (Decapoda, Portunidae) larvae in the field and in laboratory experiments
}

\author{
J. Harms, B. Meyer-Harms *, R. R. Dawirs** , K. Anger \\ Biologische Anstalt Helgoland, Meeresstation, D-27483 Helgoland, Germany
}

\begin{abstract}
The principal aim of this study was to test if biochemical and physiological data on decapod crustacean larvae from laboratory experiments can be used for the interpretation of comparable field data. Different parameters measured under identical conditions in laboratory-reared and fieldcollected larvae of Carcinus maenas were compared with each other. The parameters used were: dry weight (W), elemental composition (C, N), protein and lipid content, activities of digestive enzymes (amylase, trypsin), respiration, and ammonia excretion. Effects of different laboratory diets (Artemia sp., diatoms and no food, representing near optimal, suboptimal and starvation conditions respectively) were evaluated as a possible base for the interpretation of field data. Field data were in a similar range to laboratory data, with the exception of dry weight and protein:lipid ratio. Comparison of pooled data sets for total larval development showed lower nitrogen and higher protein contents (in \% of $\mathrm{W}$ ) in field samples than in laboratory cultures, resulting in different $N$ :protein relations. Best agreement in these parameters was found between field data and laboratory data from phytoplankton-fed or starved larvae, whereas exclusively Artemia-fed larvae showed higher percentages of $C, N$, and lipid. Larval $W$ in stages later than zoea Il was consistently higher in the field. The protein content (in $\mu \mathrm{g}$ ind. ${ }^{-1}$ ) was higher in the field as compared with laboratory cultures, resulting in a lower lipid:protein ratio. Comparison of lipid data and digestive enzyme activities under different nutritional conditions in the laboratory and in field samples shows that nutrition is limited in the field, and phytoplankton may constitute a major component of the natural diet of C. maenas larvae. This conclusion is confirmed by direct evidence from gut fluorescence and scanning electron microscopic (SEM) examination of faecal pellets. Our study suggests that laboratory data on the physiology and biochemistry of decapod larvae may be a useful tool for the evaluation of field data.
\end{abstract}

KEY WORDS: Crab larvae - Larval nutrition - Larval growth · Plankton

\section{INTRODUCTION}

Biomass accumulation and energy uptake during the larval development of decapod crustaceans have been measured in a wide variety of species reared in the laboratory under optimal feeding conditions (Anger et al. 1989, Harms 1990). Only a few attempts have been made to use laboratory data to predict production

\footnotetext{
Present addresses:

- Institut für Ostseeforschung Warnemünde. Seestraße 15. D-18119 Warnemünde, Germany

- Universität Bielefeld, Fakultät für Biologie, Postfach

100131, D-33615 Bielefeld, Germany
}

(Lindley 1988) or development rates (Anger 1983, Dawirs 1985) in the field. Such predictions, however, should generally be considered with caution (Ikeda 1977), especially as field data on growth and biochemical composition of meroplanktonic stages under natural conditions are still sparse (Steiff 1989, Meyer 1992, Meyer-Harms \& Harms 1993), and they indicate different growth rates in laboratory-reared and fieldcollected larvae.

Decapod larvae cultivated in the laboratory are mainly fed with zooplankton (Artemia sp. nauplii) in biomass concentrations exceeding naturally available average food concentrations (for discussion see Anger \& Dawirs 1981). This may partly explain growth dif- 
ferences observed between laboratory-reared and field-collected larvae. Recent experimental studies described effects of different diets on crab larvae, showing impaired growth rates and altered biochemical composition when phytoplankton instead of Artemia sp. was given as food (Harms \& Seeger 1989, Harms et al. 1991). However, data from both the laboratory and field show that decapod larvae do eat phytoplankton, especially diatoms, which must therefore be considered at least an additional food source under natural conditions (Meyer-Harms \& Harms 1993).

Since larval growth and survival in the field may highly depend on nutritional conditions (Incze \& Paul 1983), and little is known about the natural diet of decapod larvae, more detailed investigations of feeding, growth and biochemical composition of natural populations are needed to estimate their planktonic development duration and production in the field. At the same time, more biochemical and physiological measurements obtained under different controlled (i.e. experimental) nutritional conditions are necessary as a reference base for a better interpretation of field data. With such laboratory data as a relative scale, ranging from starved to well fed, it should be possible to evaluate the prevailing feeding conditions in the natural environment by comparison of data on growth, body composition, and metabolic rates. In the present paper, an attempt is made to compare laboratory with field data and to draw conclusions on natural nutrition and growth in larvae of a common decapod crustacean species.

Carcinus maenas lives in boreal coastal areas (Christiansen 1969), where its larvae are found in the plankton from spring to autumn (Rees 1952, 1955). The larvae occur in particularly high abundance in the German Bight (North Sea) from June to July (Steiff 1989), forming up to $70 \%$ of the total mesozooplankton population (W. Greve \& B. Steiff pers. comm.). The present study compares growth [measured as dry weight, elemental (C,N) and biochemical (protein, lipid) composition], respiration, ammonia excretion, and activities of digestive enzymes (amylase, trypsin) in larvae reared under different controlled feeding conditions in the laboratory with values obtained from fieldcollected larvae. This combined approach was chosen, because all such analyses have their particular limitations, e.g. biomass described as dry weight is influenced by inorganic compounds (Anger 1984), respiration and excretion are influenced by the moulting cycle (Anger \& Jacobi 1985), and digestive enzyme activities show a comlex relationship with the amount of food ingested (Harms et al. 1991). The hypothesis that phytoplankton is a regular, at least additional, food source for decapod larvae in the field was examined also directly by the fluorescence and scanning electron microscopy (SEM) examination of faecal pellets.

\section{MATERIAL AND METHODS}

Laboratory experiments. Ovigerous Carcinus maenas were collected near Helgoland (North Sea) in March 1987 and maintained individually in flow-through aquaria. Freshly hatched, actively swimming larvae were collected in sieves ( $250 \mu \mathrm{m}$ mesh size) receiving the water from an overflow (Anger \& Dawirs 1981). The larvae were mass-reared (zoea I: $\mathrm{n}=50$; zoea II: $\mathrm{n}=40$; zoea III: $\mathrm{n}=30$; zoea IV and megalopa: $\mathrm{n}=20$ ) in $400 \mathrm{ml}$ glass bowls with filtered ( $1 \mu \mathrm{m}$ pore size) natural seawater $(30$ to $32 \% \mathrm{~S})$ at constant temperature $\left(12^{\circ} \mathrm{C}\right)$, under 5 different nutritional conditions. One group (zooplankton-fed control) was given freshly hatched Artemia sp.

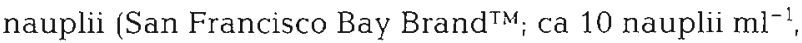
$=7.6 \mu \mathrm{g} \mathrm{C} \mathrm{ml}^{-1}$ ), while diatoms were given to 3 other groups, with concentrations corresponding to ca $1 \mu \mathrm{g} \mathrm{C}$ $\mathrm{ml}^{-1}$ (Harms et al. 1991): Odontella sinensis (60 cells $\left.\mathrm{ml}^{-1}\right)$, Thalassiosira rotula $\left(1600\right.$ cells $\left.\mathrm{ml}^{-1}\right)$, and Skeletonema costatum $\left(70000\right.$ cells $\left.\mathrm{ml}^{-1}\right)$, respectively. These concentrations were chosen after preliminary tests had shown that they were sufficient for larval nutrition, i.e. only cell size and food quality were different. These concentrations allow maximum feeding activities in other herbivorous zooplankton (Berggreen et al. 1988), and they represent maximum values in the natural pelagic environment near Helgoland (E. Hagmeier pers. comm.), exceeding 6 times the monthly average in summer blooms (Weigel \& Hagmeier 1978). The data from the 3 groups fed with different phytoplankton species were later pooled (in the following referred to as phytoplankton-fed experiments), because very similar results were obtained with these algae. Another experimental group (starved control) was maintained without food. The culture medium and food (except for the starved control) was changed daily.

In order to obtain later larval stages (zoea II to megalopa) for experiments with different feeding regimes, larvae from the same hatch were mass-reared with Artemia sp. until they reached the desired stages. Within a few hours after moulting, they were separated and transferred to the different experimental conditions (zooplankton, phytoplankton, starved). Separate experiments were started for each larval instar with larvae originating from the same female.

Food algae were cultured in $10 \mathrm{l}$ round bottom flasks in F/2 medium (Guillard \& Ryther 1962). All 3 species tested are chain-forming, but with different cell diameters: 250,40 and $10 \mu \mathrm{m}$ in Odontella sinensis, Thalassiosira rotula and Skeletonema costatum respectively. Their carbon content was estimated as $16,0.61$ and $0.014 \mathrm{ng} \mathrm{cell}^{-1}$ (E. Hagmeier pers. comm.). In experiments, only algae from cultures in the logarithmic growth phase were used as food. At regular intervals (every $2 \mathrm{~d}$ in zoeal stages, every $3 \mathrm{~d}$ in the mega- 
lopa) aliquot samples of larvae from the same hatch and with identical age within a given moult cycle were taken for analyses and stored at $-80^{\circ} \mathrm{C}$.

Field samples. Vertical plankton hauls (Calcofi, $500 \mu \mathrm{m}$ mesh size) were taken during May-July 1991 at 'Helgoland-Reede', and live Carcinus maenas larvae were isolated under a stereomicroscope. To wash off phytoplankton cells attached to the body, larvae were rinsed carefully 3 times in filtered seawater (Whatman $\mathrm{GF} / \mathrm{C}$ filter $0.45 \mu \mathrm{m}$, at $0^{\circ} \mathrm{C}$ ) and stored at $-80^{\circ} \mathrm{C}$ for later analyses. Another part of the isolated larvae was transferred live to filtered seawater to allow for defaecation. Faeces ( $n=20$ to 50) for SEM were washed 3 times in distilled water and dehydrated (ethanol battery), critical point dried, mounted on an aluminum stub with silver conducting paint, and coated with gold/palladium (Gonzales \& Biddanda 1990). SEM of pellets was performed using a Cam Scan 44 microscope. Faeces of 4 successive days were examined for each developmental stage.

Parallel to the plankton hauls, water samples from $10 \mathrm{~m}$ depth were preserved with Lugol for the determination of algae concentrations and identification of species with the method of Utermöhl (1931). Phytoplankton biomass was estimated as described by Meyer-Harms \& Harms (1993).

Biochemical and physiological measurements; statistical methods. Parallel measurements comprised dry weight (W), elemental composition (carbon, $\mathrm{C}$ hydrogen, $\mathrm{H}$, not presented here; nitrogen, N), protein, lipid, activities of digestive enzymes (amylase, trypsin), respiration, and ammonia excretion. The latter 2 measurements were made only in larvae from field samples, whereas laboratory data had to be taken from an earlier experiment (R. R. Dawirs unpubl.; zooplankton-fed larvae only); therefore, no respiration and excretion data were available for phytoplanktonfed and starved larvae. W, C and $N$ were measured for each age group in laboratory-reared larvae (8 replicates) and for field samples $(13,5,13,25$ and 9 replicates for the zoea I, II, III, IV and megalopa respectively). The samples were freeze-dried and weighed on a Mettler UM3 microbalance, then combusted in a Carlo Erba model 1106 CHN analyzer (Anger \& Harms 1990). The energy content was estimated from C applying the conversion given by Salonen et al. (1976).

Protein was measured in 5 replicates of both laboratory and field samples. Depending on individual larval body weight, the number of individuals for each replicate measurement of $\mathrm{C}, \mathrm{N}$ and protein were 30 to 40 in the zoea I, 12 to 20 in the zoea II, 8 to 12 in the zoea III, 5 to 8 in the zoea IV and 5 in the megalopa, consistently corresponding to ca $300 \mu \mathrm{g} \mathrm{W}$. Samples for lipid and enzymes measurements had about 1 to $2 \mathrm{mg} \mathrm{W}$, with 3 to 5 replicates each.
Total lipids were measured photometrically with a Merckotest reagent kit (Merck, Darmstadt, Germany), utilizing the sulphophosphovanilin reaction (Zöllner \& Kirsch 1962). Samples for protein and enzyme measurements were homogenized in $4 \mathrm{ml}$ distilled water on crushed ice using a Branson Sonifer B15 cell disrupter After centrifugation at $6000 \mathrm{rpm}(5000 \times \mathrm{g})$ for $10 \mathrm{~min}$, the supernatant was used for digestive enzyme assay (with 3 or 4 replicates). Amylase activity was measured with the method of Street \& Close (1956) at $\mathrm{pH} 6.8\left(37^{\circ} \mathrm{C}\right)$, trypsin according to Samain et al. (1977) at $\mathrm{pH} 8.3$ and $39^{\circ} \mathrm{C}$. Incubation time was 15 min. Calibration was carried out with amylase (Merck 16312; 30000 U $95 \mathrm{mg}^{-1}$ ) and trypsin (Merck 8214: $20000 \mathrm{E} \mathrm{g}^{-1}$ ) standards from bovine pancreas. The $\mathrm{pH}$ and temperature relationships of the digestive enzymes were tested and found the same as described by Hirche \& Anger (1987). Enzyme activities were calculated per individual. Protein was measured after Lowry et al. (1951) with bovine serum albumin (Merck 12018) as a standard.

Respiration was measured applying the Winkler method (Dawirs 1983, Anger \& Jacobi 1985). Parallel to oxygen consumption, ammonia excretion was measured under identical conditions, following the analytical procedure described by Solarzano (1969). For each measurement of respiration and excretion, 15 to 25 zoea I, 10 to 15 zoea II, 10 zoea III, 7 to 10 zoea IV and 4 or 5 megalopae were used. Larvae were incubated for $15 \mathrm{~h}$ in bottles with ca $55 \mathrm{~cm}^{3}$ filtered $(0.45 \mu \mathrm{m}$; Millipore) seawater. Prior to the experiments, the larvae were not fed for $2 \mathrm{~h}$ to allow for gut clearing. Each respiration and excretion measurement consisted of an experimental group (with larvae) and 5 replicate blanks (without larvae). The experimental group comprised 7 to 8 replicates in laboratory-reared larvae. The number of replicates in field samples varied depending on availability of larvae: 18 zoea I, 8 zoea II, 14 zoea III, 25 zoea IV, and 18 megalopa. The decrease of oxygen concentration in the experiments was $<15 \%$, which is believed not to affect larval respiration (Anger \& Jacobi 1985).

The chlorophyll a content in the guts of Carcinus maenas larvae was measured fluorometrically, following the method of Mackas \& Bohrer (1976). Between 20 and 150 larvae per sample (depending on size) were thawed, washed with distilled water, and homogenized by sonicating in $5 \mathrm{ml}$ cold $\left(0^{\circ} \mathrm{C}\right) 90 \%$ acetone and stored in tubes at $4^{\circ} \mathrm{C}$ in the dark. Three replicates were processed for each analysis, and 7 to 10 analyses were done for each larval stage.

Mean values (Table 1) were compared with each other by a 2-tailed t-test (Sachs 1968, p. 272). Regression coefficients were compared after Sachs (1968, p. 428). 


\section{RESULTS}

The ranges of individual dry weight $\left(W_{1}\right.$ in $\mu g$ ind $\left.^{-1}\right)$ and relative ( $\%$ of $W$ ) contents of carbon (C), nitrogen $(\mathrm{N})$, protein, and lipid measured in the laboratory under different nutritional conditions as well as those in field samples are compiled in Table 1 for all larval stages of Carcinus maenas. Since these parameters change significantly within each moulting cycle, minimum and maximum values give a better overview of variations in these parameters under different nutritional conditions as compared to mean values and standard deviations. Except in the first 2 developmental stages, larvae from field samples had significantly higher $\mathrm{W}$ than laboratory-cultured larvae. The relative contents of $\mathrm{C}$ and lipid from field samples were closest to those in phytoplankton-fed and starved larvae. However, larvae from field samples had higher relative protein contents in the first 2 zoeal stages as compared with those in laboratory cultures.
C, $N$, protein, and lipid contents (\% of W) did not vary significantly during larval development, regardless of the feeding condition. When the data were pooled disregarding the stage of development, significant variation in the average body composition was found between different nutritional conditions in the laboratory and in field samples (Fig. 1). Highest percentage values of these parameters were found in zooplankton-fed larvae (Artemia), second highest in the phytoplanktonfed group, and lowest in the starved control. In larvae from field samples, the $\mathrm{C}$ content reached values intermediate between those in the starved control and in phytoplankton-fed larvae. Percentage $\mathrm{N}$ and lipid values were very low, but protein values were high in the field. The weight-specific energy content of larval biomass showed a similar pattern to $C$, from which it was estimated. Lowest variation was found in the $C: N$ ratio.

The absolute (per individual) values of $\mathrm{W}, \mathrm{C}$ and $\mathrm{N}$ are given in Fig. 2. The first 2 zoeal stages showed in the field intermediate values between those in phyto-

Table 1 Carcinus maenas. Minimum and maximum values of dry weight ( $\mu$ ind $^{-1}{ }^{-1}$ ) and percentage content of carbon, nitrogen, protein and lipid in larval stages measured at 3 different nutritional conditions (zooplankton, phytoplankton, starved control) in the laboratory, and under field conditions. Significantly higher (H) and lower (L) mean values in laboratory than in field data are indicated $(" p<0.05, \cdots p<0.01, \cdots p<0.001 ; 2$-tailed $t$-test); ns: no significant differences

\begin{tabular}{|c|c|c|c|c|c|c|c|c|c|c|c|c|c|c|c|c|}
\hline \multirow[t]{2}{*}{ Stage } & \multirow{2}{*}{$\begin{array}{l}\text { Data source } \\
\text { Food condition }\end{array}$} & \multicolumn{3}{|c|}{ Dry weight $(\mu \mathrm{g})$} & \multicolumn{3}{|c|}{$\%$ Carbon } & \multicolumn{3}{|c|}{$\%$ Nitrogen } & \multicolumn{3}{|c|}{$\%$ Protein } & \multicolumn{3}{|c|}{ \% Lipid } \\
\hline & & Min. & $\operatorname{Max}$ & $\mathrm{p}$ & Min & Max. & $\mathrm{p}$ & Min. & Max. & $\mathrm{p}$ & Min. & Max. & $\mathrm{p}$ & Min. & Max. & $\mathrm{p}$ \\
\hline \multirow[t]{5}{*}{ Zoea I } & Laboratory & & & & & & & & & & & & & & & \\
\hline & Zooplankton & 9.7 & 15.1 & $\mathrm{H}^{\bullet}$ & 35.6 & 38.3 & ns & 8.1 & 8.9 & $\mathrm{H}^{\cdots}$ & 23.4 & 26.8 & ns & 6.1 & 8.6 & $\mathrm{H}^{\cdots}$ \\
\hline & Phytoplanton & 9.7 & 12.0 & ns & 30.9 & 35.0 & ns & 7.4 & 8.6 & $\mathrm{H}^{*}$ & 19.4 & 22.0 & L $\cdots$ & 4.8 & 5.3 & ns \\
\hline & Starved & 8.5 & 9.8 & ns & 29.8 & 36.2 & $L^{\bullet}$ & 7.1 & 9.3 & ns & 19.2 & 21.5 & $L^{\bullet}$ & 4.0 & 4.3 & ns \\
\hline & Field & 7.6 & 14.6 & & 30.5 & 35.1 & & 6.3 & 8.5 & & 25.2 & 36.6 & & 2.3 & 5.6 & \\
\hline \multirow[t]{5}{*}{ Zoea II } & Laboratory & & & & & & & & & & & & & & & \\
\hline & Zooplankton & 18.9 & 29.7 & ns & 35.6 & 40.4 & $\mathrm{H} \cdots$ & 7.7 & 8.7 & $\mathrm{H}^{\cdots}$ & 23.7 & 24.9 & $L^{*}$ & 8.7 & 9.7 & $\mathrm{H}^{\bullet}$ \\
\hline & Phytoplankton & 18.4 & 23.0 & ns & 31.0 & 36.2 & $\mathrm{H}^{*}$ & 7.4 & 8.5 & $\mathrm{H} \cdots$ & 17.7 & 21.8 & $L^{\cdots}$ & 4.1 & 5.2 & ns \\
\hline & Starved & 11.4 & 16.2 & $\mathrm{~L} \cdots$ & 28.9 & 32.3 & ns & 6.9 & 8.1 & $\mathrm{H}^{*}$ & 19.3 & 21.8 & $\mathrm{~L}^{*}$ & 4.3 & 4.4 & ns \\
\hline & Field & 18.0 & 26.2 & & 28.3 & 33.0 & & 4.1 & 6.2 & & 23.6 & 42.1 & & 2.3 & 9.0 & \\
\hline \multirow[t]{5}{*}{ Zoea III } & Laboratory & & & & & & & & & & & & & & & \\
\hline & Zooplankton & 27.1 & 46.5 & L $\cdots$ & 37.5 & 41.9 & $\mathrm{H} \cdots$ & 7.8 & 9.2 & $\mathrm{H} \cdots$ & 26.8 & 29.2 & ns & 8.8 & 12.6 & $\mathrm{H}^{\bullet}$ \\
\hline & Phytoplankton & 28.6 & 38.6 & $L^{\cdots}$ & 32.3 & 36.8 & $\mathrm{H} \cdots$ & 7.7 & 9.4 & $\mathrm{H} \cdots$ & 24.8 & 27.2 & ns & 4.8 & 5.4 & $\mathrm{H}^{\cdots}$ \\
\hline & Starved control & 25.4 & 29.8 & $\mathrm{~L}^{\cdots}$ & 29.8 & 35.3 & ns & 7.2 & 8.2 & $\mathrm{H}^{\prime} \cdot$ & 22.0 & 22.3 & $\mathrm{~L}^{*}$ & 3.8 & 4.3 & ns \\
\hline & Field & 48.1 & 65.7 & & 30.2 & 35.9 & & 4.8 & 7.3 & & 21.9 & 40.4 & & 1.3 & 2.7 & \\
\hline \multirow[t]{5}{*}{ Zoea IV } & Laboratory & & & & & & & & & & & & & & & \\
\hline & Zooplankton & 40.9 & 73.7 & L' & 41.2 & 45.7 & $\mathrm{H} \cdots$ & 8.3 & 9.9 & $\mathrm{H}^{\cdots}$ & 32.7 & 33.1 & ns & 13.6 & 14.7 & $H^{\cdots}$ \\
\hline & Phytoplankton & 48.1 & 58.7 & L $\cdots$ & 34.4 & 39.3 & $\mathrm{H}^{\cdots}$ & 7.9 & 9.7 & $\mathrm{H}^{\cdots \cdots}$ & 25.6 & 28.4 & ns & 5.0 & 5.4 & $\mathrm{H}^{\cdots}$ \\
\hline & Starved & 38.2 & 45.5 & L $\cdots$ & 30.9 & 37.1 & $\mathrm{~ns}$ & 7.4 & 8.7 & $\mathrm{H}^{\cdots}$ & 23.1 & 24.7 & $L^{*}$ & 4.4 & 5.6 & $\mathrm{H}^{\prime}$ \\
\hline & Field & 68.51 & 124.0 & & 30.9 & 37.1 & & 6.4 & 8.4 & & 26.5 & 33.7 & & 1.6 & 3.7 & \\
\hline \multirow[t]{5}{*}{ Megalopa } & Laboratory & & & & & & & & & & & & & & & \\
\hline & Zooplankton & 93.11 & 154.1 & $L^{\prime} \cdots$ & 37.9 & 39.6 & $\mathrm{H}^{\cdots}$ & 7.6 & 8.9 & $\mathrm{H}^{*}$ & 30.0 & - & & 8.8 & - & \\
\hline & Phytoplankton & 99.51 & 116.3 & $L^{\prime} \cdots$ & 27.3 & 33.8 & $L \cdots$ & 6.3 & 7.9 & ns & 24.7 & 29.1 & ns & 1.0 & 2.2 & ns \\
\hline & Starved & 84.51 & 107.9 & L $\cdots$ & 27.8 & 30.9 & $\mathrm{~L} \cdots$ & 6.2 & 7.2 & ns & 12.9 & 27.0 & ns & 1.6 & 2.1 & ns \\
\hline & Field & 180.6 & 266.3 & & 31.2 & 37.1 & & 6.6 & 7.7 & & 25.4 & 34.3 & & 0.9 & 2.3 & \\
\hline
\end{tabular}



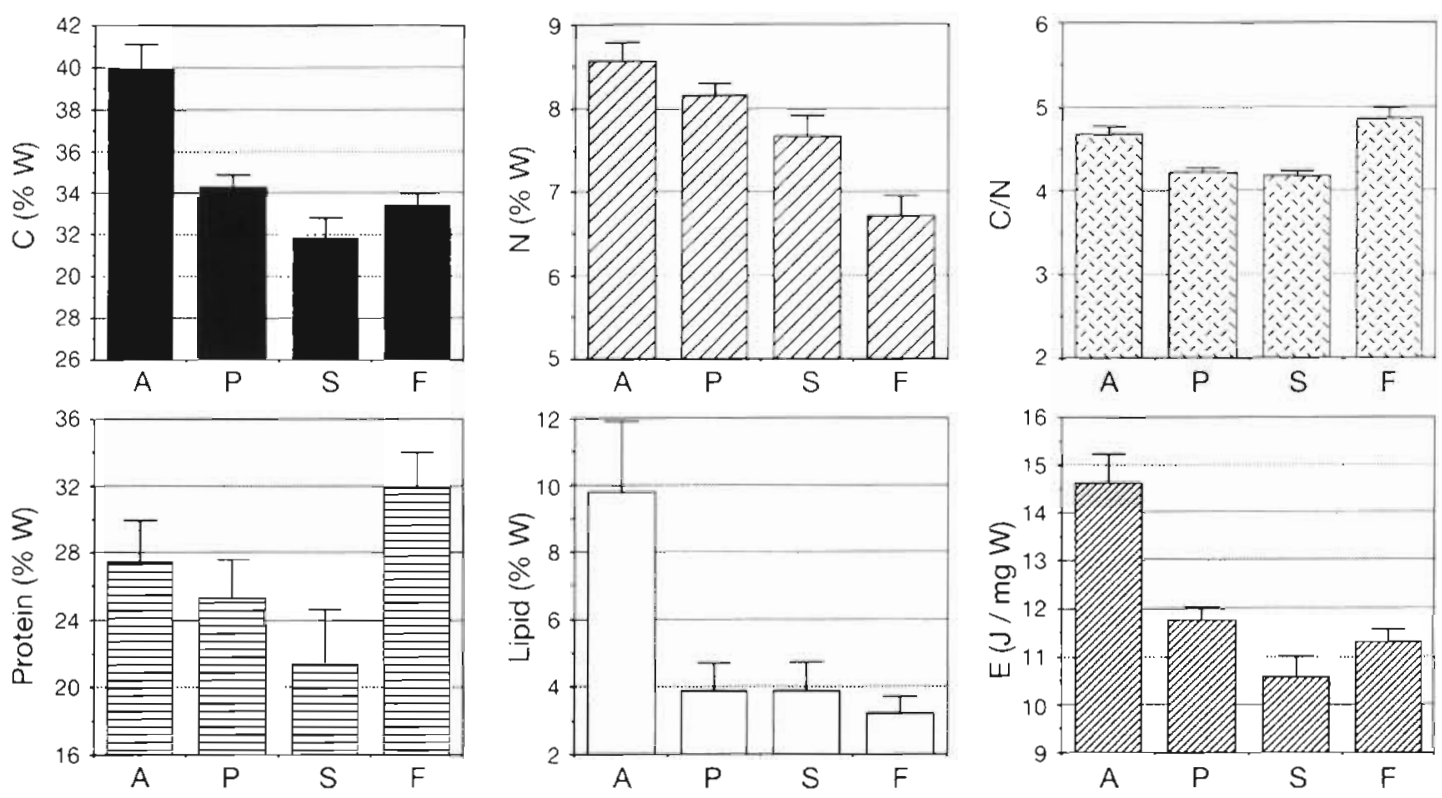

Fig. 1. Carcinus maenas. Average body composition of larvae reared in the laboratory under 3 different nutritional conditions (A: fed Artemia sp. = zooplankton; P: phytoplankton; S: starved control) and from field samples (F). Carbon (C), nitrogen (N), protein, lipid, C:N weight ratio, and energy content ( $E$, estimated from C, after Salonen et al. 1976), in relation to dry weight (W); arithmetic means $\pm 95 \%$ confidence interval

plankton-fed and starved larvae. In field samples, however, later larval stages gained more biomass per individual than those in the laboratory, although the percentage $\mathrm{C}$ and $\mathrm{N}$ values remained lower in field samples (Table 1). This was caused by significantly higher average $W$ in larvae from the field. Mean values in the zoea III, IV and megalopa stages were 57, 104 and $223 \mu \mathrm{g}$ ind. $^{-1}$ respectively, which is 42 to $64 \%$ higher than in Artemia-fed laboratory larvae.

Changes in the lipid:protein ratio (Fig. 3) did not show the patterns expected from the C:N ratio (Fig. 1). This ratio was consistently lowest in larvae collected in the field. Comparable values were found only in field-caught, phytoplankton-fed and starved megalopa larvae (Fig. 3), whereas generally higher values were found in larvae fed with Artemia. Second highest were in general measured in the phytoplankton-fed group. and consistently lowest values in the starved control.

Metabolic activity (expressed as weight-specific respiration rate; Fig. 4) was similar in laboratoryreared larvae fed Artemia and in those collected from the field, except for the zoea I. This stage revealed in field samples $40 \%$ lower respiration, but 2.5 times higher ammonia excretion than in laboratory-reared larvae (Fig. 4). This indicates that zoea I larvae in field samples were catabolizing chiefly proteins. All other zoeal stages did not show significant differences between field and laboratory data. Respiration and excretion in laboratory-cultured megalopae were slightly lower as compared to those in field samples.
Digestive intensity was measured as activity of amylase and trypsin (Fig. 5); no data were available for the megalopa stage in laboratory-cultured larvae. The activites of both digestive enzymes tested increased in general during larval development. Highest amylase activity was found in laboratory-reared zoea I and II larvae fed Artemia and in phytoplankton-fed zoea III and IV, while lowest activitiy was detected in the zoea I from field samples. Zoea II, III and IV larvae in the field had similar values to phytoplankton-fed or starved larvae in the laboratory, respectively. The activity of trypsin decreased in general with deteriorating nutritional quality (i.e. in the order: Artemia-fed, phytoplankton-fed, starved). Only in the zoea III were highest values observed in phytoplankton-fed larvae. Lowest trypsin activities were in general measured in field-collected larvae.

The available phytoplankton stock was quantified by the Utermöhl method during the period from 10 May to 24 July (Fig. 6). Total phytoplankton concentrations were intermediate to low, with a decreasing trend during the first 3 wk of this period, thereafter they increased again. This tendency was particularly strong in diatoms, which were almost absent until the end of May, whereas flagellates dominated within the phytoplankton during the initial phase and decreased later. During the first $3 \mathrm{wk}$, which were characterized by low availability of planktonic algae, predominantly zoea I and zoea II larvae appeared. Maximum numbers of later larval stages followed thereafter, during June and July, when phytoplankton concentrations were much higher. 

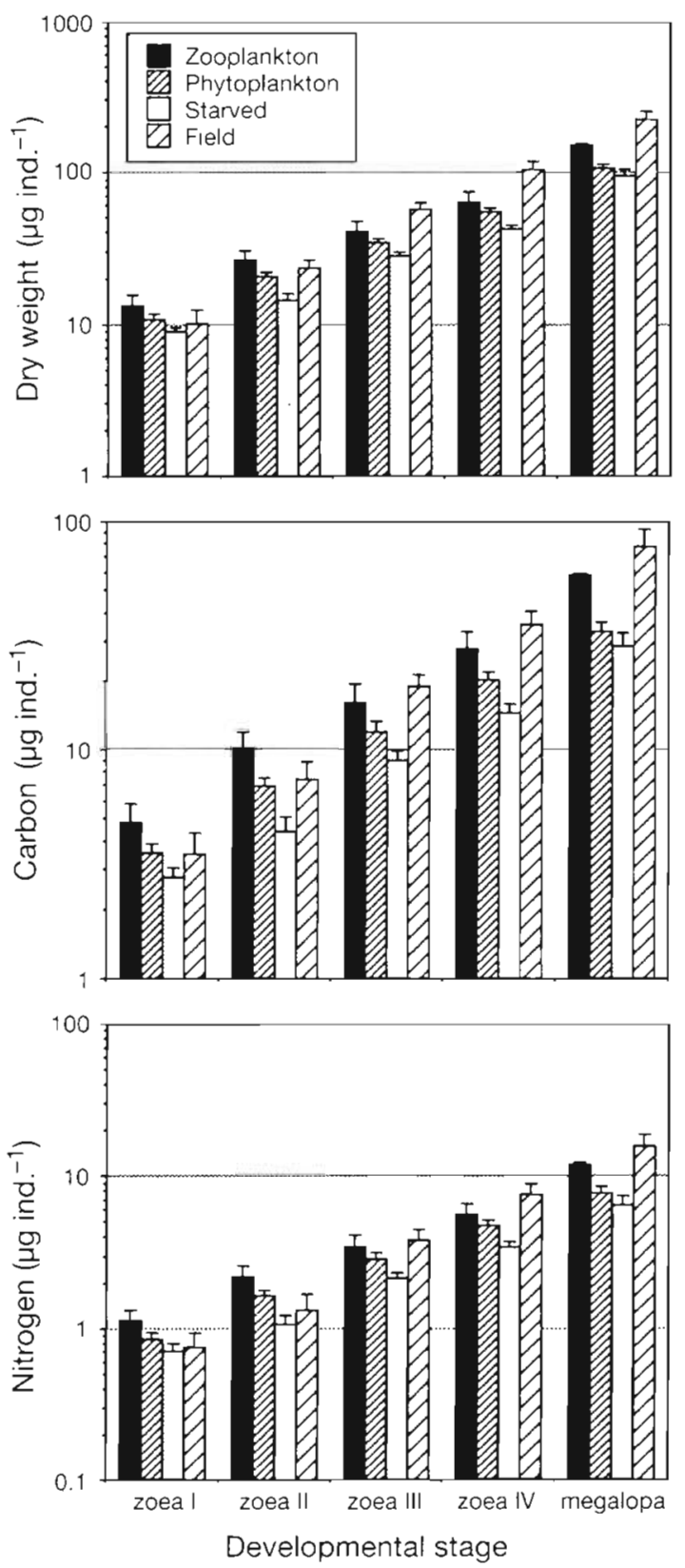

Fig. 2. Carcinus maenas. Dry weight, carbon and nitrogen contents of larvae reared in the laboratory under 3 different nutritional conditions (fed zooplankton, phytoplankton and starved controls) and from field samples

Gut fluorescence of Carcinus maenas larvae measured during the same study period provides evidence that all developmental stages do ingest phytoplankton in the field (Fig. 7). Chlorophyll concentration in the gut was relatively high in the first, reached a minimum in the second, and increased again with development through all later larval stages. This pattern of variation coincides with that observed in the available phytoplankton stock (Fig. 6)

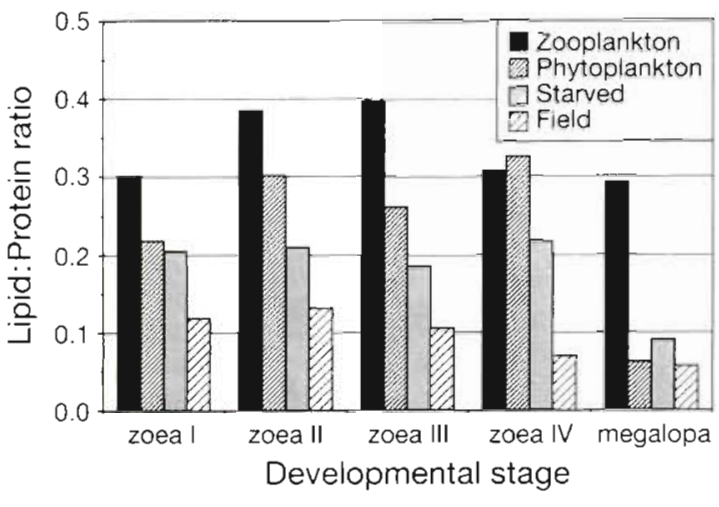

Fig. 3. Carcinus maenas. Lipid:protein ratio in larvae reared in the laboratory under 3 different nutritional conditions (fed zooplankton, phytoplankton and starved controls) and from field samples
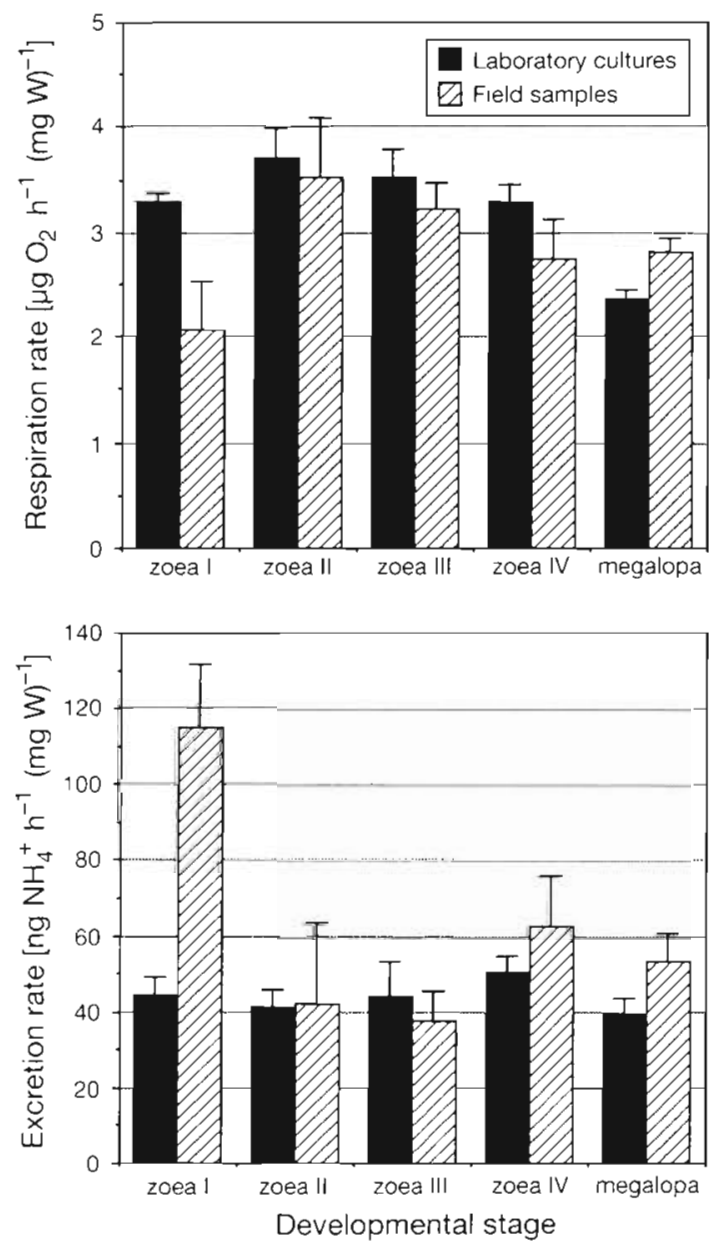

Fig. 4. Carcinus maenas. Weight-specific respiration and excretion rates in larvae reared in the laboratory $\left(\right.$ at $12{ }^{\circ} \mathrm{C}$ ) with zooplankton (Artemia sp.) and in the field (zoea I: $9^{\circ} \mathrm{C}$, zoea II and III: $11^{\circ} \mathrm{C}$, zoea IV $12^{\circ} \mathrm{C}$, megalopa $15^{\circ} \mathrm{C}$, according to the water temperature during the sampling period) 

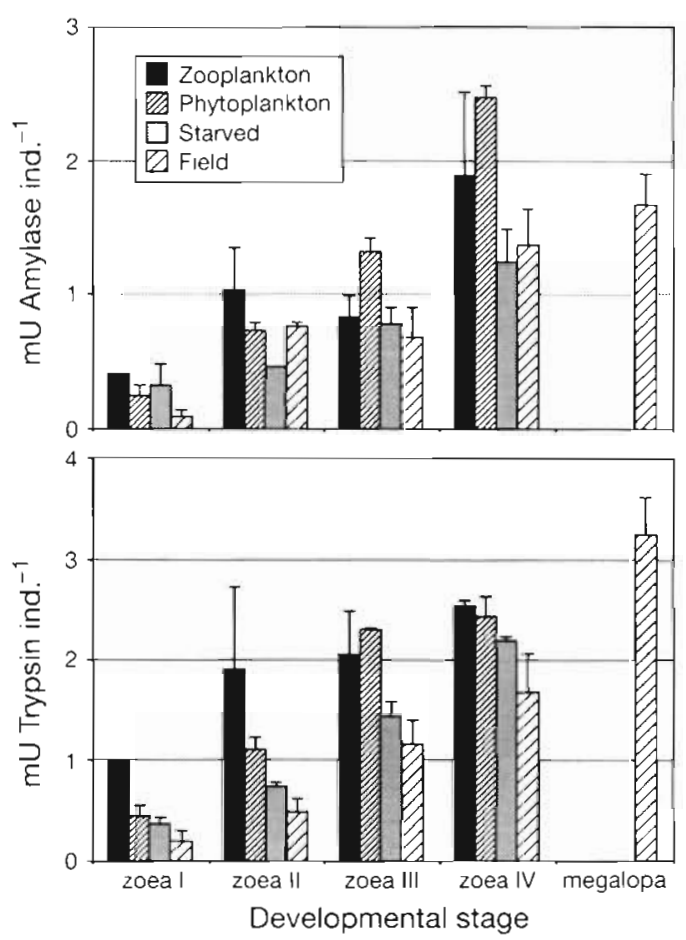

Fig. 5. Carcinus maenas. Digestive enzyme activities (amylase, trypsin) in larvae reared in the laboratory under 3 different nutritional conditions (fed zooplankton, phytoplankton and starved controls) and from field samples

Further evidence for the ingestion of phytoplankton by crab larvae was found in faecal pellets that were collected during the same period. Fragments of diatoms (Fig. 8) could be identified in most faeces ( $72 \%$ ) that were examined with SEM. Only in the zoea II could no such fragments be detected; this corresponds to low gut fluorescence measured independently in this larval stage (Fig. 7), and it coincides with low phytoplankton concentrations in the water during the time of its appearance (Fig. 6).

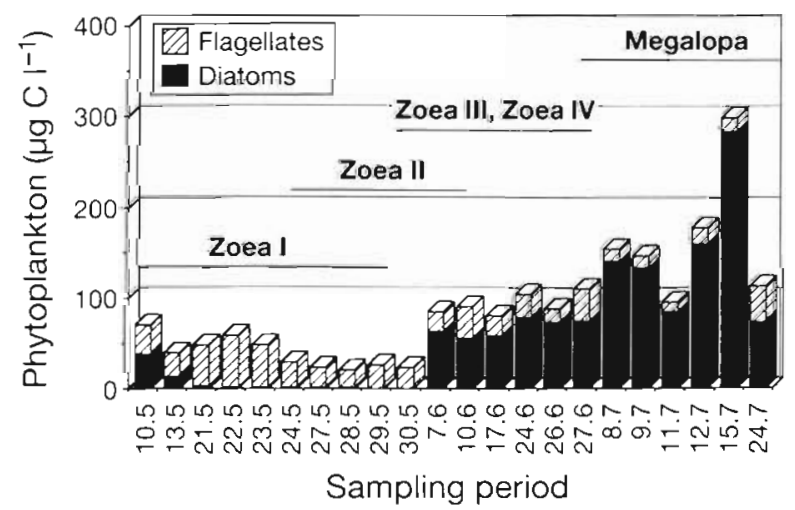

Fig. 6. Carcinus maenas. Phytoplankton concentrations and maximum appearance of subsequent larval stages during a sampling period from 10 May to 24 July 1991

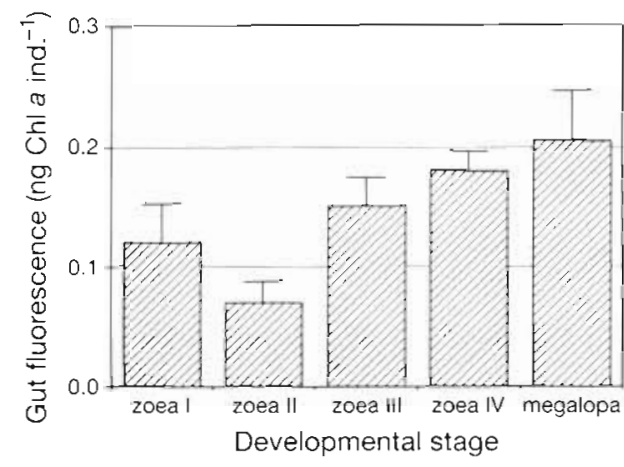

Fig. 7. Carcinus maenas. Gut fluorescence in larvae collected in the field, 10 May to 24 July 1991

\section{DISCUSSION}

Available field and laboratory data on growth and energy accumulation in decapod larvae are often not directly comparable due to different sampling strategies. Planktologists often use size fractions for the quantification of biomass and turnover rates (Ikeda 1985, Weisse 1985, Postel et al. 1992). In laboratory studies, growth and metabolic activities of single species and developmental stages can be precisely analysed in short term intervals (Anger 1990, and literature cited therein), however, the natural environment can be simulated only to a certain degree in laboratory experiments. Predictions of growth or time and success of development in the field on the basis of laboratory data (e.g. Anger 1983, Darwirs 1985, Lindley 1988, 1990) assume that larvae react and behave under laboratory conditions similar to those in the field. Ikeda (1977) showed that such predictions must be considered with some caution. Although urgently needed, comparison of laboratory and field data was made by only a few authors (Steiff 1989, Meyer 1992, MeyerHarms \& Harms 1993). The information given in the present study shows that, with a few exceptions, laboratory and field data of known species and developmental stages are well comparable. Thus, we conclude that experimental data can be used for the evaluation of the nutritional condition of meroplanktonic larvae under natural conditions.

It is obvious that larval stages later than zoea II had higher $W$ in the field than in laboratory cultures. This phenomenon, which had already been described by Knight (1968), Ebert et al. (1983) and Steiff (1989), may be explained by higher accumulation of inorganic compounds from natural food (e.g. by ingestion of diatom shells, inorganic detritic particles, etc.). This interpretation, however, needs scrutiny in future analyses that should include ash measurements 


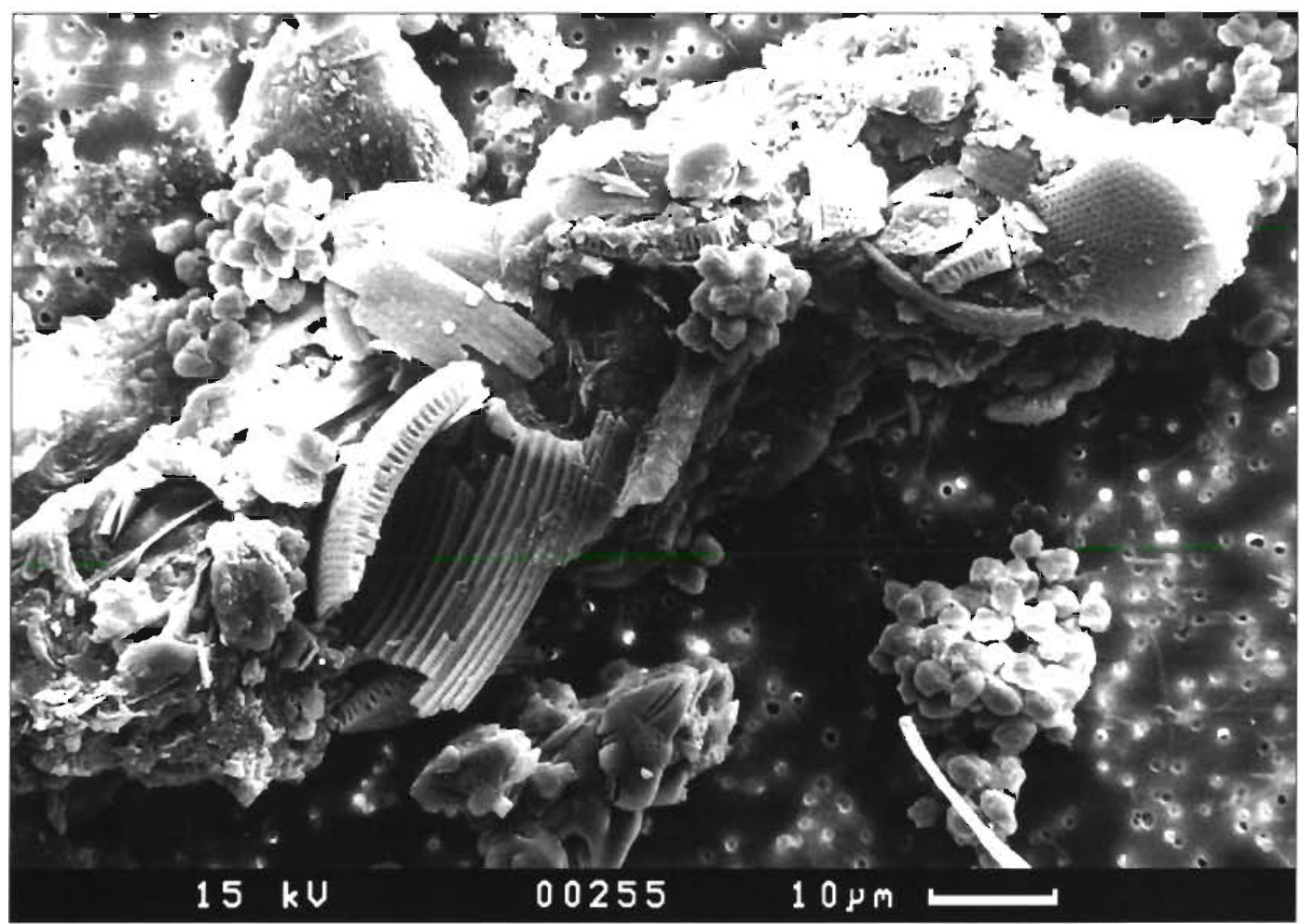

Fig. 8. Carcinus maenas. Scanning electron microscopic examination of faeces from larvae (zoea III) collected in the field on 17 June. Fragments of Podosira stelliger can be identified (G. Drebes pers. comm.)

The most striking difference between laboratoryreared and field-sampled Carcinus maenas larvae was that in the relationship between protein and nitrogen. In the literature (e.g. Youngbluth 1982, Vollenweider 1985), protein is often calculated from total $\mathrm{N}$, using a constant conversion factor of 6.25 , although in the strict sense this is only applicable to protein-N. A non-linear relationship is obtained when protein is plotted against $N$ (Fig. 9), with protein values consistently lower than those calculated from the theoretical factor 6.25. Although larvae from field samples had particularly low nitrogen contents relative to $W$, they showed the highest protein contents (Fig. 1), resulting in a different relationship between $\mathrm{N}$ and protein content as compared to larvae from laboratory cultures (Fig. 9). The intersect with the $y$-axis differs significantly in these regression lines $(p<0.05)$, whereas their slopes were not significantly different.

This demonstrates that larvae collected in the field had in all larval stages a higher proportion of nitrogen fixed in the protein fraction as detected by the Lowry method (Lowry et al. 1951). Hence, we presume that laboratory-cultured larvae have a higher pool of oligopetides or free amino acids that contain $\mathrm{N}$ but are not detected by the Lowry method. Such compounds may be utilized by larvae in the field to build up muscles, possibly because they need to swim more actively than in laboratory cultures. Another possible explanation might be an interference of ingested substances with the Lowry method. Larvae may have ingested algae containing phenolics. However, the diatoms tested here do not appear to interfere with the Lowry method, because no differences were found in the relationship between $N$ and protein in the experimental group fed phytoplankton. The relationship between $\mathrm{N}$ and protein found here for Carcinus maenas larvae reared in the laboratory (all nutritional conditions) is similar to that described for other larval decapods (Anger \& Harms 1990).

Although generally high $\mathrm{C}$ and low lipid contents were found in crab larvae from the field (Figs. 1 \& 2), no statistically significant difference was found between the (positive) correlations of $C$ and lipid observed in laboratory-reared and field-collected larvae, respectively. Field data, however, consistently revealed a somewhat lower lipid level in relation to $\mathrm{C}$. The slope of the overall regression between $C$ and lipid shown in Fig. 9 differs from that given by Anger \& Harms (1990) for brachyuran larvae. This may be caused by a much smaller range of biomass values used in the present study $(\mathrm{C}$ values varied here from 2.8 to $77 \mu \mathrm{g}$ ind. ${ }^{-1}$, those given by Anger \& Harms from 2.4 to 
$250 \mu \mathrm{g} \mathrm{C}$ ind.-1), or it may be an effect of the different nutrtional conditions tested. Differences between larvae from laboratory cultures and field samples (with minimum values in the latter) were found also in the lipid:protein ratios; this was caused by significantly higher protein and slightly reduced lipid contents in field-collected larvae.

The prevailing metabolic substrate my be ascertained with the $O: N$ ratio (Mayzaud \& Conover 1988). In larvae collected in the field, it was generally similar to that in Artemia-fed larvae, except for the zoea I (Fig. 10). In the field, this stage revealed a predominantly protein-orientated metabolism (atomic $O: N$ ratio $<20$ ), whereas the zoea II and III catabolized more lipids and/or carbohydrates ( $\mathrm{O}: \mathrm{N}>60)$. The metabolism in the zoea IV and megalopa was based on the utilization of mixed substrates. Unfortunately, no respiration and excretion values of phyto-
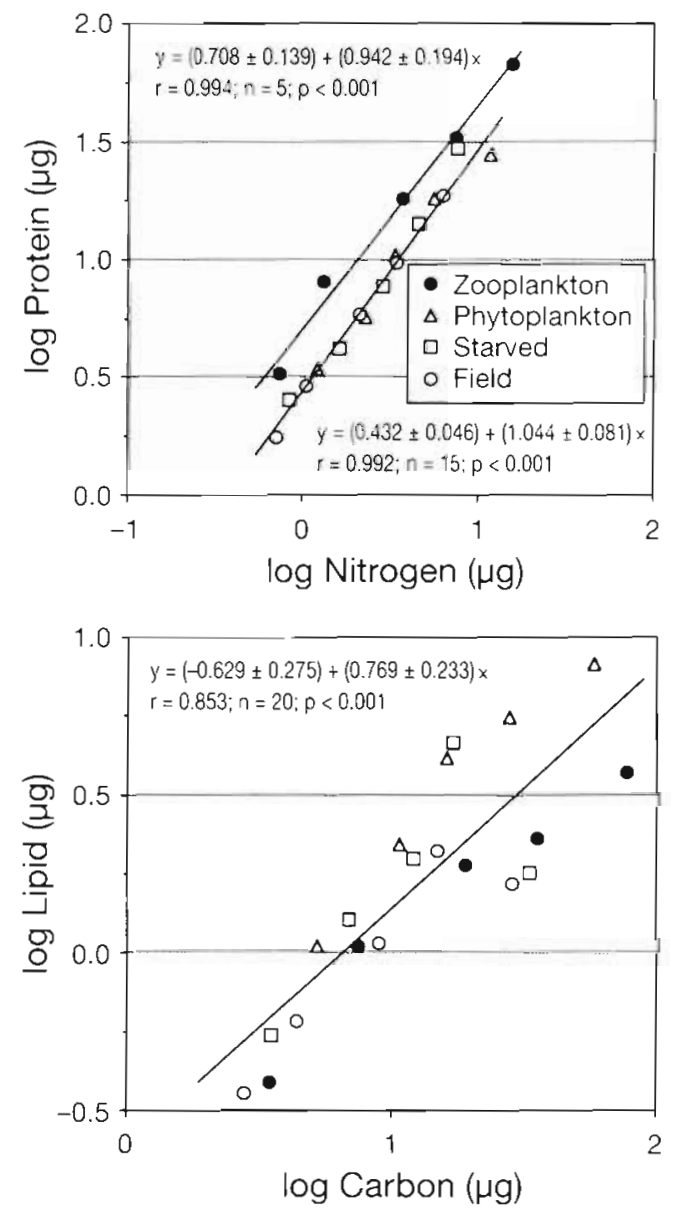

Fig. 9. Carcinus maenas. Relation (on a log-log scale) between nitrogen and protein, and between carbon and lipid in larvae reared in the laboratory at 3 different nutritional conditions (fed zooplankton, phytoplankton, and starved control) and from field samples

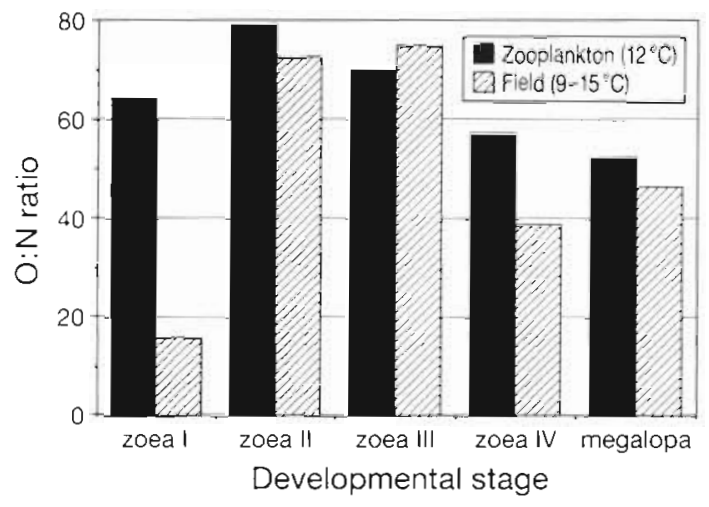

Fig. 10. Carcinus maenas. Atomic $\mathrm{O}: \mathrm{N}$ ratio in larvae reared in the laboratory with Artemia sp. (zooplankton) and in field samples

plankton-fed or starved larvae were available, so that no statement can be made about variation of the $O: N$ ratio in relation to the nutritional status. It is known that decapod larvae utilize protein reserves during long starvation periods, after lipid reserves are depleted (Anger 1986, Harms et al. 1991). The proteinorientated metabolism in the zoea I might therefore be an indication of low food availability in the field. Food limitation has been suggested being a common phenomenon in the natural pelagic environment (Thorson 1950, Conover 1968, Conover \& Mayzaud 1975, Turner \& Mittelbach 1990). The presumption of a starvation situation for the zoea $\mathrm{I}$ in the field is supported also by similarity of $\mathrm{W}$ and percentage $\mathrm{C}$ and $\mathrm{N}$ data with those in starving laboratory larvae (Table 1).

The activities of digestive enzymes are often used as a relatively simple method to determine in situ feeding activity (Boucher et al. 1975, Samain et al. 1975). The activity of amylase was in some cases found to be related to the amount of chlorophyll or carbohydrates available in the planktonic enviroment (Boucher et al. 1975, Mayzaud \& Poulet 1978, Hirche 1981), although the substrate of amylase (starch) is not present in diatoms and seldom in other marine phytoplankton groups (Gaudy \& Boucher 1983). Thus, the activity of laminarinase should be a better indicator for herbivorous nutrition (Cox 1981). This enzyme digests chrysolaminarin, the main storage product of most phytoplankton (Haug \& Myklestad 1973). However, the activities of amylase and laminarinase were found to be closely linked with each other (Meyer 1992) supporting the suggestion by Harms et al. (1991) that these carbohydrases may be activated by a single control factor. The amylase:laminarinase ratio in Carcinus maenas larvae varied around a value of 5 in the zoeal stages and 4 in the megalopa respectively (Meyer 1992). 
Digestive enzyme activities measured in this study were in the range observed in other zooplankton organisms (Samain et al. 1980, Hirche 1981, Båmstedt 1988). The only other decapod larvae where digestive enzyme activities had been measured in the laboratory (Hyas araneus with Artemia sp. as a diet) showed significantly higher activities of both amylase and trypsin (Hirche \& Anger 1987, Harms et al. 1991). Hirche \& Anger (1987) found amylase in larvae fed exclusively with zooplankton (Artemia sp.) and interpreted this as a phylogenetic relic, suggesting that trypsin and amylase were co-regulated by a single factor. Recent data on the natural feeding behaviour of $H$. araneus larvae showed that they also ingest phytoplankton (Thalassiosira sp.) in considerable amounts in the natural environment (Meyer-Harms \& Harms 1993). More detailed investigations on digestive enzyme activities in meroplanktonic larvae are needed to evaluate the relationship between different enzymes and the diet ingested.

Meroplankton can constitute a substantial proportion of zooplankton biomass, particularly in inshore waters. For instance, the larvae of an anomuran crab Pisidia longicornis may contribute up to $90 \%$ of the total zooplankton biomass in the Ria de Arosa, Spain (Tenore et al. 1982), and Williams \& Collins (1986) found that meroplankton, the dominant constituents of which were decapod larvae, accounts for up to $58 \%$ of the omnivore biomass in the Bristol Channel, England. The lack of knowledge on the natural feeding behaviour and growth in seasonally important organisms is obvious. More detailed investigations in the field, separating larvae to the species level and into developmental stages, are necessary for the quantification of developmental processes, grazing activities and biomass accumulation during their planktonic life.

Our field data of growth, biochemical composition and metabolic activity in Carcinus maenas larvae agree well with data measured under laboratory conditions. Comparison of data sets, especially of digestive enzyme activity and lipid content, in laboratory cultures and field samples gave evidence that phytoplankton is a major component of the natural diet of Carcinus maenas larvae. This was shown also directly by gut fluorescence and SEM examinations of faecal pellets. The grazing activity of $C$. maenas larvae may be similar to that in herbivorous copepods (Bantista \& Harris 1992). Further comparison of field and laboratory data (the latter obtained under different nutritional conditions) will form a future platform for the evaluation of the nutritional condition of meroplankton in the field.

Acknowledgements. Our special thanks to the crew of RV 'Aade' for their assistance and regular supply with plankton samples. We are indebted to Dr E. Hagmeier (Biologische
Anstalt Helgoland) for providing algal cultures and Mrs C. Püschel for her assistance in CHN analysis. Mrs B. Kohn and Mrs B. Seeger assisted in the experiments. We thank Dipl.-Ing. R. Bahlo (Institut für Ostseeforschung) for the SEM examination of the faecal pellets. Our thanks also to 3 anonymous referees for suggestions that helped to improve this paper. This investigation was partly supported by the Deutsche Forschungsgemeinschaft, Bonn (Grant An-145/2-2).

\section{LITERATURE CITED}

Anger, K. (1983). Temperature and the larval development of Hyas araneus L. (Decapoda, Majidae); extrapolation of laboratory data to field conditions. J. exp. mar. Biol. Ecol. 69: $203-215$

Anger, K. (1984). Gain and loss of particulate organic and inorganic matter in larval and juvenile spider crabs (Hyas araneus) during growth and exuviation. Helgoländer Meeresunters. 38: 107-122

Anger, K. (1986). Changes of respiration and biomass of spider crab (Hyas araneus) larvae during starvation. Mar. Biol 90: 261-269

Anger, K. (1990). Modelling developmental changes in the carbon and nitrogen budgets of larval brachyuran crabs. Helgoländer Meeresunters. 44: 53-80

Anger, K., Darwirs, R. R. (1981). Influence of starvation on the larval development of Hyas araneus (Decapoda, Majidae). Helgoländer Meeresunters. 34: 287-311

Anger, K., Harms, J. (1990). Elemental (CHN) and proximate biochemical composition of decapod crustacean larvae. Comp. Biochem. Physiol. 97B: 69-80

Anger, K., Harms, J., Montu, M., Bakker, C. (1989). Growth and respiration during the larval development of a tropical spider crab, Libinia ferreirae (Decapoda, Majidae). Mar. Ecol. Prog. Ser. 54: 43-50

Anger, K., Jacobi, C. C. (1985). Respiration and growth of Hyas araneus L. larvae (Decapoda: Majidae) from hatching to metamorphosis. J. exp. mar. Biol. Ecol. 88: 257-270

Båmstedt, U. (1988). Interspecific, seasonal and diel variations in zooplankton trypsin and amylase activities in Kosterfjorden, western Sweden. Mar. Ecol. Prog. Ser. 44: 15-24

Bautista, B., Harris, R. P. (1992). Copepod gut content, ingestion rates and grazing impact on phytoplankton in relation to size structure of zooplankton and phytoplankton during a spring bloom. Mar. Ecol. Prog. Ser. 82: 41-50

Berggreen, U., Hansen, B., Kiorboe, T (1988). Food size spectra, ingestion and growth of the copepod Acartia tonsa during development: implications for determination of copepod production. Mar. Biol. 99: 341-352

Boucher, J., Laurec, A., Samain, J. F., Smith, S. L. S. (1975). Etude de la nutrition du régime et du rythme alimentaire du zooplankton dans les conditions naturelles par la mesure des activités enzymatiques digestives. In: Persoone, G., Jaspers, E. (eds.) 10th Eur. mar. Biol. Symp., Vol. 2. Universa Press, Wetteren, p. 85-110

Christiansen, M. E. (1969). Crustacea Decapoda Brachyura. Mar. Invertebr. Scand. 2: 1-143

Conover, R. J. (1968). Zooplankton life in a nutritionally dilute environment. Am. Zool. 8: 107-118

Conover, R. J., Mayzaud, P. (1975). Respiration and nitrogen excretion of neritic zooplankton in relation to potential food supply. In: Persoone, G., Jaspers, E. (eds.) 10th Eur. mar. Biol. Symp., Vol. 2. Universa Press, Wetteren, p. 151-163

Cox, J. L. (1981). Laminarinase induction in marine zooplankton and its variability in zooplankton samples. J. Plankton Res. 3: $345-356$ 
Dawirs, R. R. (1983). Respiration, energy balance and development during growth and starvation of Carcinus maenas L. larvae (Decapoda: Portunidae). J. exp. Mar. Biol. Ecol. 69: $105-128$

Dawirs, R. R. (1985). Temperature and larval development of Carcinus maenas (Decapoda) in the laboratory; predictions of larval dynamics in the sea. Mar. Ecol. Prog. Ser. 24: 297-302

Ebert, E. E., Haseltine, A. W., Houk, J. L., Kelly, R. O. (1983) Laboratory cultivation of the Dungeness crab, Cancer magister. In: Wild, P. W., Tasto, R. N. (eds.) Life history, environment, and mariculture studies of the Dungeness crab, Cancer magister, with emphasis on the central California fishery resource. Calif. Dep. Fish Game Fish Bull. 172: $259-309$

Gaudy, R., Boucher, J. (1983). Relation between respiration, excretion (ammonia and inorganic phosphorus) and activity of amylase and trypsin in different species of pelagic copepods from an Indian Ocean equatorial area. Mar. Biol. 75: $37-45$

Gonzales, H., Biddanda, B. (1990). Microbial transformation of metazoan (Idotea granulosa) faeces. Mar. Biol. 106 285-295

Guillard, R. R. L., Ryther, J. H. (1962). Studies of marine planktonic diatoms 1. Cyclotella nana Hustedt and Detonula confervacea (Cleve) Gran. Can. J. Microbiol. 8 $229-239$

Harms, J. (1990). Accumulation and loss of biomass in LioCarcinus holsatus larvae during growth and exuviation Mar. Biol. 104: 183-190

Harms, J., Anger, K., Klaus, S., Seeger, B. (1991). Nutritional effects on ingestion rate, digesive enzyme activity, growth and biochemical composition of Hyas araneus L. (Decapoda: Majidae) larvae. J. exp. mar. Biol Ecol. 145: 233-265

Harms, J., Seeger, B. (1989). Larval development and survival in seven decapod species (Crustacea) in relation to laboratory diet. J. exp. mar. Biol. Ecol. 133: 129-139

Haug, A., Myklestad, S. (1973). Studies on the phytoplankton ecology of the Trondheimsfjord. I. The chemical composition of phytoplankton populations. J. exp. mar. Biol. Ecol. 11: $15-26$

Hirche, H.-J. (1981). Digestive enzymes of copepodids and adult of Calanus finmarchicus and C. hyperboreus in relation to particulate matter. Kieler Meeresforsch. 5: 174-185

Hirche, H.-J., Anger, K. (1987). Digestive enzymes activities during larval development of Hyas araneus (Decapoda, Majidae). Comp. Biochem. Physiol. 87B: 297-302

Ikeda, T (1977). The effect of laboratory conditions on the extrapolation of experimental measurements to the ecology of marine zooplankton. IV. Changes in respiration and excretion rates of boreal zooplankton species maintained under fed and starved conditions. Mar. Biol. 41: 241-252

Ikeda, T (1985). Metabolic rates of epipelagic marine zooplankton as a function of body mass and temperature Mar. Biol. 85: 1-11

Incze, T., Paul, A. J. (1983). Grazing and predation as related to energy needs of stage I zoea of the tanner crab Chinoecetes bairdi (Brachyura: Majidae). Biol. Bull. 165: 197-208

Knight, M. D. (1968). The larval development of Blepharipoda occidentalis Randall and $B$. spinimana (Philippi) (Decapoda, Albuneidae). Proc. Calif. Acad. Sci. 35: 337-370

Lindley, J. A. (1988). Estimating biomass and production of pelagic larvae of brachyuran decapods in western European shelf waters. J. exp. mar. Biol. Ecol. 122: 195-211

Lindley, J. A. (1990). Regressions for estimating development times of the pelagic larvae of Paguridae and Porcellanidae. J. Plankton Res. 12: 673-678
Lowry, D. H., Rosenberg, N. J., Farr, A. L., Randall, R. J (1951). Protein measurement with the folin phenol reagent. J. Biol. Chem. 193: 265-275

Mackas, D. L., Bohrer, R. (1976). Fluorescence analysis of zooplankton gut contents and investigation of diel feeding patterns. J. exp. Mar. Biol. Ecol. 25: 77-85

Mayzaud, P., Conover, R. J. (1988). O:N atomic ratio as a tool to describe zooplankton metabolism. Mar. Ecol. Prog. Ser 45: 289-302

Mayzaud, P., Poulet, S. A. (1978). The importance of the time factor in the response of zooplankton to varying concentrations of naturally occurring particulate matter. Limnol Oceanogr. 23: 1144-1154

Meyer, B. (1992). Freilanduntersuchungen zur Ernährung von Dekapoden-Larven. M.Sc. thesis, Universität Kiel

Meyer-Harms, B., Harms, J. (1993). Detection of phytoplankton pigments by HPLC in Hyas araneus larvae (Crustacea, Decapodal: comparison of field and laboratory data. Neth. J. Sea Res. 31. 153-161

Postel, L., Hernandez Leon, S., Gomez, M., Torres, S., Mikkat, U., Portillo Hahnefeld, A. (1992). Zooplankton oxygen consumption and nutrient release in relation to species composition, animal size and environmental conditions in the Baltic Sea during May and August. Int. Coun. Explor Sea C.M. 1992 L: 21. 1-16

Rees, C. B. (1952). Continuous plankton records: the decapod larvae in the North Sea 1947-1949. Bull. mar. Ecol. 22 $157-184$

Rees, C. B. (1955). Continuous plankton records: the decapod larvae in the North Sea 1950-51 Bull. mar. Ecol. 29 $69-80$

Sachs, L. (1968). Statistische Auswertungsmethoden. SpringerVerlag, Berlin

Salonen, K., Sarvala, J., Hakala, I. Viljanen, M.-L. (1976). The relation of energy and organic carbon in aquatic invertebrates. Limnol. Oceanogr. 21: 724-730

Samain, J. F., Boucher, J., Buestel, D. (1975) Signification biologique des teneurs protéiques et des activités de l'amylase et des protéases chez Artemia salina L. Aspects d'application à l'étude de la nutrition. In: Persoone, G., Jaspers, E. (eds.) 10th Eur. mar Biol. Symp. Vol 1 Universa Press, Wetteren, p. 391-417

Samain, J. F., Daniel, J. Y., Le Coz, J. R. (1977). Trypsine, amylase et protéines du zooplancton: dosage automatique et manuel. J. exp. mar. Biol. Ecol. 29: 279-289

Samain, J. F., Moal, J., Daniel, J. Y., LeCoz, J. R., Jezequel, M. (1980). The digestive enzymes amylase and trypsin during the development of Artemia: effect of food conditions. In: Persoone, G., Sorgeloos, P., Roels, O., Jaspers, E. (eds.) The brine shrimp Artemia, Vol. 2. Universa Press, Wetteren, p. 239-255

Solarzano, L. (1969). Determination of ammonia in natural waters by the phenolhypochlorite method. Limnol. Oceanogr. 14: 799-801

Steiff, B. (1989). Die Brachyurenlarven (Crustacea: Decapoda) in der Deutschen Bucht: Vorkommen, Entwicklung Verbreitung. Ph.D. dissertation, Universität Hamburg

Street, H. V., Close, J. R. (1956). Determination of amylase activity in biological fluids. Clin. Chim. Acta 1. $256-268$

Tenore, K. R., Boyer, L. F., Cal, R. M., Corral, J., GarciaFernandez, C., Gonzalez, N., Gonzalez-Gurriaran, E., Hanson, R. B., Iglesias, J., Krom, M., Lopez-Jamar, E., McClain, J., Pamatmat, M. M., Perez, A., Rhoads, D. C.. de Santiago, G., Tietjen, J., Westrich, J., Windom, H. L. (1982). Coastal upwelling in the Rias Bajas, N.W. Spain contrasting the benthic regimes of the Rias de Arosa 
and de Muros. J. mar. Res. 40: 701-772

Thorson, G. (1950). Reproduction and larval ecology of marine bottom invertebrates. Biol. Rev. 25: 1-45

Turner, A. M., Mittelbach, G. G. (1990). Predator avoidance and community structure: interactions among piscivores, planktivores, and plankton. Ecology 71: 2241-2254

Utermöhl, H. (1931). Über das umgekehrte Mikroskop. Int. Ver. theor. angew. Limnol. 5: 567-596

Vollenweider, R. A. (1985). Elemental and biochemical composition of plankton biomass; some comments and explorations. Arch. Hydrobiol. 105: 11-29

Weigel, H. P., Hagmeier, E. (1978). Chlorophyll, phytoplankton carbon, and nutrients off Helgoland. Annls biol., Copenh. 33: 72-73

This article was submitted to the editor
Weisse, T. (1985). Die Biomasse und Stoffwechselaktivität des Mikro- und Mesozooplanktons in der Ostsee. Ber. Inst. Meereskunde 144:1-127

Williams, R., Collins, N. R. (1986). Seasonal composition of meroplankton and holoplankton in the Bristol Channel. Mar. Biol. 92: 93-101

Youngbluth, M. J. (1982). Utilization of a fecal mass as food by the pelagic mysis larva of the penaeid shrimp Solenocera atlantidis. Mar. Biol. 66: 47-51

Zöllner, N., Kirsch, K. (1962). Über die quantitative Bestimmung von Lipoiden (Mikromethode) mittels der vielen natürlichen Lipoiden (allen bekannten Plasmalipoiden) gemeinsamen Sulfophosphovanillin-Reaktion. Z. ges, exp. Med. 135: 545-561

Manuscript first received: July 13,1993

Revised version accepted: February 21, 1994 